\title{
Del descubrimiento de América: Los "tesoros" llevados a España después del primer viaje
}

Jaime Alberto López Nuila

Cristóbal Colón informa a la Corona Española de su descubrimiento de "Las Indias", afirmando que aquellas Comunidades que ahora conoce y que habitaban las Antillas en la época del 1492, apenas alcanzaban un desarrollo comparable al Neolítico Superior de la Europa de entonces. Investigaciones Arqueológicas comprueban luego, en épocas modernas, que las Antillas, todas, fueron originalmente pobladas, probablemente siglos antes del descubrimiento, y en forma gradual, por pueblos diversos provenientes de las Cuencas de los ríos Orinoco, en Venezuela, y Xingu y Tapajos en las Guayanas, pertenecientes a los muchos grupos aborígenes de la parte Noreste del Continente Sud Americano ${ }^{1}$.

Todos esos grupos de Indígenas que habitaban Regiones Costeras, estaban habituadas al uso ancestral de pequeñas canoas para el desarrollo de su propio estilo de vida; eran hábiles pescadores y marinos que también necesitaban trasladarse utilizando los cauces de los grandes ríos continentales. Quizá por su habilidad y su natural conocimiento de un litoral que les era próximo y muy familiar, tal vez por espíritu de aventura, ó por una difícil sedentarización y apego a la agricultura, lo cierto es, que comenzó una práctica de migración que en forma progresiva, partió de aquellas costas y empezó a ocupar las Islas del vecino Caribe, y fueron de ese modo poblándose aquellas Islas desde tiempos anteriores a la era Cristiana. Fue, según queda dicho, realizada en forma permanente, por años, a través de sucesivas oleadas migratorias a lo largo de siglos, hasta permitir que para 1492 todas las Islas estuviesen ocupa-

\footnotetext{
1 Véase al respecto, Frank Moya Pons. Manual de historia dominicana. $6^{\text {a }}$. Edición. Barcelona, España. Año 1981.
} 
das. Esto queda comprobado con el hecho de que Colón a su regreso a España, y como testimonio de sus logros, se hace acompañar por decenas de Indígenas que fueron sustraídos de las diferentes Islas.

La Investigación Arqueológica demuestra luego que esas ocupaciones, previas al descubrimiento, las Antillas, lo fueron en lo que parece ser ciertos momentos bien diferenciados que llamaremos Fases de la Ocupación. La primera está representada por pueblos que pertenecen a la llamada Cultura de Concha y que se distingue por su carácter

Primitivo, localizados a orillas de la Costa, pantanos y ríos, y que, sin conocimiento alguno de la Agricultura tampoco practica ni conoce la Alfarería. Son los pueblos Siboneyes que se asientan especialmente en Cuba. La Segunda Fase de la Ocupación aborigen de las Islas de las Antillas, corresponde al nivel Arqueológico llamado igneri provenientes del tronco común Arahuaco, que ocupan todas las Antillas menores hasta Puerto Rico y la Isla la Española, ocupación que permite la absorción ó la eliminación de los grupos de Siboneyes que les precedieron. Ya practican la Alfarería, que alcanza niveles de desarrollo y perfección reconocidos en la Historia del desarrollo de los pueblos de las Antillas.

La Tercera Fase de la ocupación aborigen se estructura con base en una amplia expansión de la migración Arahuaca y, por su superior desarrollo, permite la final eliminación de los núcleos de Siboneyes que todavía sobreviven en Haití, Cuba, Jamaica y las Bahamas, salvándose solo pequeños grupos en la parte occidental de Cuba y según parece, en el extremo occidental de la parte Sur de Haití. En este tercer período, fundada tal vez en la abundante y numerosa población, es cuando se puede encontrar el desarrollo Independiente de lo que son tradiciones culturales continentales que permite que surja lo que posteriormente al descubrimiento, se conocerá como Sociedad Taína, que forma parte de la cultura aborigen que encuentra Colón en la época del descubrimiento.

Existe, como se anticipaba, una Cuarta Fase en la población de las Islas de las Antillas y que se inicia en épocas tardías, más o menos en el Siglo XI, y que se representa con nuevas y vigorosas incursiones de nuevas poblaciones, distintos de los pueblos primeros, Igneris y Tainos. Son los Caribes, grandes navegantes, expertos en el uso del arco y la flecha, que por su fortaleza y número aplastarían pronto a los pobladores originales. La mas conocida de las 
características del pueblo Caribe es por otra parte su vocación a la Antropofagia que los llevó a través de su lucha de conquista, a consumir la carne de sus adversarios hombres, y en la mayoría de casos, destinar a las mujeres a la esclavitud, sirviéndoles como cocineras, tejedoras ó alfareras ${ }^{2}$.

El origen Sud Americano de los aborígenes de las Islas del mar Caribe se fortalece con la adopción de costumbres como el uso del tabaco, la forma de construcción de sus viviendas, el cultivo del maíz, el uso de la hamaca y la forma y estilo de construcción de sus canoas. Para la llegada de Colón los pueblos Caribes habían penetrado ya lo suficiente en las Sociedades que les precedieron, especialmente los Taínos, un proceso de aculturación que produce al final, la comunidad de ambos pueblos, renunciando los Caribes a su canibalismo y a prácticas de guerra como el procedimiento de envenenar sus flechas, y también a su propia lengua, adoptando por su parte los Taínos las prácticas de la caza y la pesca que hacen los Caribes, quizá, por su superior desarrollo y efectividad naciendo así una comunidad mas estable y organizada, capaz de imponerse por sobre aquellos pueblos pacíficos ó inocentes que les habían precedido en su arribo a aquellas Islas ${ }^{3}$.

Cuando Cristóbal Colón concibe la gesta del descubrimiento, es cierto que debió esforzarse mucho, en distintos sitios, y ante varios Estados como Francia, Inglaterra y Portugal, hasta que los Reyes de Castilla se interesaron por sus ofrecimientos. Ocupada España con la guerra de Granada, y ya para su término, Colón envió una carta a la Reina, entregada a ésta por medio del Padre Fray Juan Pérez, dándole a su recibo la respuesta de que Colón recibiría los tres navíos que solicitaba. La ayuda real sería de 20,000 florines, recibida casi de inmediato. Cristóbal Colón solicitaba para sí, como recompensa, su estado como Almirante, Visorey y Gobernador perpetuo de las tierras por descubrir, lo que, no obstante rechazos iniciales, fue finalmente aceptado por los Reyes ${ }^{4}$.

Colón prometía grandes bienes y riquezas con su descubrimiento. Luis de Santangel, escribano de raciones y allegado al Palacio, habló de esto justamente con la Reina, afirmándole que el viaje de Colón, era un negocio de

\footnotetext{
2 Ibid, Pags. 7,8,9,10.

3 Véase al respecto, Fray Bartolomé de las Casas. Historia de las Indias. Sociedad Dominicana de bibliófilos. Santo Domingo. República Dominicana. Tomo I. Pág. 145. Año 1987.

4 Ibid. Tomo I. Cap. XXXI. Pags. 164 y sgts.
} 
calidad. Colón también solicitó y obtuvo de los Reyes, además de las distinciones antes citadas, promesa de la décima parte de todas las perlas preciosas, oro, plata, especiería y otras cosas que se obtuviesen por los actos del descubrimiento. Todo lo convenido fue suscrito por los Reyes de Castilla, a los 30 días del mes de Abril de 1492. Acontece también, que como siempre se creyó que para encontrar tierras firmes é Islas, allende el mar, había de topar Colón, con los Reinos del Gran Khan-(China) y las tierras riquísimas del Catay, pidió también Colón cartas reales para el Gran Khan, y también para todos los Reyes y Señores de las Indias, y de cualquiera otra parte que hallase en las tierras que descubriese.

Todos los detalles de la gesta del descubrimiento, desde la búsqueda del apoyo del soberano, hasta la consecución misma de la Empresa, incluidos los pleitos legales con Martín Alonso Pinzón, compañero de viaje y en cierto modo, también auspiciador económico de la gran Empresa, quien reclamaba para sí la mitad de todo lo que se había prometido a Colón, resultan pequeños ante el hecho incontrovertible de que fue la ambición por supuestas riquezas, inmensas é inagotables, lo que movió todos los resortes de aquella novedosa expedición. Estas expectativas resultan ciertas en todo lo expresado por cuanto el descubrimiento, a la postre, significó para España la entrada a un Estado de progreso y de esplendor nunca antes visto, precisamente por las inmensas riquezas, sobre todo en oro, que fueron sustraídas del nuevo mundo, pero, por lo menos de resultas del primero de sus viajes y a su regreso a Castilla, lo que Cristóbal Colón lleva como prueba de su descubrimiento es diferente a aquello que, posiblemente, todos querían y esperaban.

Para la ciencia y para la humanidad, la aventura y el valor de aquel grande hombre que confió en sus ideas hasta el fin, produjo los resultados que marcan un punto importante en la historia del mundo. Un mundo desconocido era abierto para la conquista, como tenía que ser. Para Castilla y para sus soberanos permite que aquel gran país ascienda hasta los más grandes niveles que nunca había conocido, colocándoles como la primera nación, la más poderosa del mundo conocido hasta ese entonces. Colón, buscando las Indias, descubre América. Ningún documento histórico permite afirmar que la expedición de Colón saliese en busca de las tierras descubiertas. Fue hasta 1507 que la Cartografía de la época registra el Continente descubierto.

Para la Ciencia, el conocimiento de aquellas tierras lejanas, con personas distintas, con animales y plantas desconocidas, es un paso adelante en el desarro- 
1lo humano. La zoología, la botánica, la medicina, la navegación, el comercio y la economía, dan grandes pasos adelante, quizás el más grande que alguna vez se haya permitido dar la humanidad en su historia. Este es el logro del descubrimiento, pero, el primer viaje de Colón, no conduce de regreso a España ni perlas preciosas, ni oro, ni plata, ni especiería nueva. Eso tendría que esperar aún unos cuantos años, hasta que la conquista del Nuevo Mundo se pudiese concretar. Entonces aparecerán las riquezas sin fin que provee América, pero ello ya no será parte de la obra de Colón.

El tesoro obtenido por Cristóbal Colón en su primer viaje, recogido por el descubridor en persona, fue un tesoro zoológico, botánico y etnológico. El comprobó sus afirmaciones de que el Nuevo Mundo no era África, pero también dejó al descubierto que tampoco había llegado a las tierras del gran Khan ó de las riquísimas tierras del Catay, y de todas las Indias que el ansiaba descubrir. No fue una desilusión para Colón, porque nunca admitió ningún error en sus proyectos. Es que Colón tampoco tenía en su primer viaje el propósito de colonizar, por esa razón sus disposiciones fueron las de no parar, porque ese primer viaje solo tenía como propósito descubrir ${ }^{5}$.

Cristóbal Colón muere desconociendo la realidad del Mundo que recién acaba de descubrir, y convencido de haber llegado al lejano Oriente citado por Marco Polo. El estaba apurado por regresar a Castilla, convencido del éxito de su Empresa y en busca del reconocimiento, de la fama y la riqueza que estimaba le correspondía. Dispuso así recoger un tesoro é Inventario de indicios en el Nuevo Mundo para llevar consigo como pruebas de su éxito marítimo. El inventario de los primeros objetos recogidos por Colón se clasifica en oro, algodón, piedras, cera, animales y plantas é indios naturales.

El hallazgo de oro fue sin duda principal preocupación del Almirante, y siendo algunos objetos de uso personal del Indígena, como partes de cintas y carátulas, plastas y coronas, narigueras y orejeras, todos incrustados ó adornados con oro, se dio a la tarea de colectar todo lo que pudo obtener del indígena, las mas de las veces, por canje por adornos sin valor traídos de Castilla. Observó Colón que el indígena almacenaba a veces, cantidades muy importantes de algodón en sus viviendas, y, estimando muy inteligentemente, un uso promisorio del producto en Europa, también colectó miles de quintales de algodón,

5 Véase al respecto, Fray Bartolomé de las Casas. Historia de las Indias. Sociedad Dominicana de bibliófilos. Santo Domingo. República Dominicana. Tomo I. Pág. 244. Año 1987. 
hilado y también obrado en la forma de naguas, paños y mantillas que las mujeres vestían; también hamacas y cintos que eran elaborados con algodón. También otros materiales como ser; Piedras provenientes de cauces de ríos, relucientes y de color aurífero fueron recolectadas é identificadas como margaritas y cera. Colón llevó también un panal de abejas de la Isla de Cuba. En lo que respecta a la Fauna, este es el mas grande sector de pruebas y evidencias recogidas por Cristóbal Colón en su primer viaje, explicando el Almirante, que despiertan su interés sobre todo porque los considera totalmente diferentes a las especies Europeas, entre los que destacan clases diferentes de peces, aves, reptiles, moluscos y crustáceos. Hay variedades de peces como toninos, dorados, oplondunas, atunes, peje puerco. Entre las variedades de aves destacan el grajao, rabiforcado, añade, el alcatraz, papagayos verdes ó cotorras, los ánsares ó gallinitas domésticas. Reptiles como la iguana ó sierpe y moluscos como caracoles ó crustáceos como el cangrejo.

En lo que respecta a la flora: Entre éstas están el lináloe, la almáciga, el ají, y muchas otras muestras que Colón confesó no poder identificar. Había frutas como el cazabe de la yuca y los ajes ó batatas que incluso fueron con anterioridad consumidas como alimento por los españoles. En lo referente a las armas: Entre estos objetos, que servirían a los naturales mas que como Instrumentos de ataque ó defensa, mas bien para la caza y la pesca, están tales como un palo, una caña, un palillo, una tablilla, azagayas, armas arrojadizas con un palo aguado y diente de pez en la punta, arcos y muchas flechas, una espada, una macana.

Los indígenas: Colón retuvo a muchos naturales de la tierra a la que habían arribado, con el propósito de extraer de ellos toda la información posible y los secretos de sus comunidades. Fueron muchos y de todos los sitios a que arribó, así, en Guanahani tomó entre 6 ó 7 varones y mujeres; en Cuba 7 mujeres, 5 varones 3 niños, en Samaná detuvo a 4 jóvenes y en Haití un número que De las Casas dice no poder establecer.

En sus crónicas y respecto al secuestro de estas personas, Cristóbal Colón expresa, casi como una banal excusa, que sustrae y lleva consigo a aquellas personas "para que aprendiesen la lengua de Castilla". En otros momentos, tanto el Almirante como diferentes cronistas, se darán un suspiro y un remanso en sus conciencias, afirmando que el propósito era "enseñar a aquellos la fé católica". 
El Intercambio: Los Europeos recibían, casi siempre voluntariamente del Indígena, todo lo que poseía, y es que para el Europeo la media y la norma en su llegada fue encontrar sumisión, rendición, admiración, a sus personas, por parte de seres indefensos. Algunas veces también hubo que hacer intercambio de baratijas y toda clase de objetos sin valor, a cambio de los bienes de los indios. Llegaron al fin a comprar al mismo individuo, cuando el Europeo pasó de la emoción y el encanto inicial con su llegada a la ambición y al deseo de aprovecharse de todo aquello, y de todos aquellos, que se le ofrecían en sus manos.

Hubo entrega de cascabeles, monedas sin valor alguno, bacinetas, arambeles, hojas de latón, sartas de cuentas, vignio, hacines, vasijas de barro, tijeras y cuchillos, anillos, agujas, alfileres, guantes, camisas de lienzo, paños de colores, capuces, todas, cosas que fueran calificadas por De las Casas como simple bagatela. Toda esta bisutería y cosas sin valor, era el pago que el Indígena recibió en un principio y mientras el Europeo aprendía a vivir en las nuevas tierras por todo lo que él poseía en este mundo. Al final le quitarían sus mujeres y también sus propias vidas.

Los naturales de las Islas descubiertas, según cuenta De las $\operatorname{Casas}^{6}$ que en los primeros momentos después de temores justificados, y creyendo que "los cristianos venían del cielo" optaban por huir de ellos por lo que Colón certifica a los Reyes "que 10 hombres hagan huir a 10,000, según le parecieron cobardes y medrosos, sin armas, que no tienen sino unas varas con un palillo tostado al cabo de ellas". Los españoles mostraron su poder exhibiendo muy "valientes" sus ballestas armadas y la mostraban a los indios, diciéndoles que les mataría a todos porque aquella ballesta hería de lejos y mataba. Ante los Indios, desnudos y sorprendidos, también sacaron su espada de la vaina, mostrándoles que mataba ante lo que "oído por ellos, dieron todos a huir quedando todavía temblando el dicho indio de cobardía".

El mismo español confiesa que el indio natural de aquellas tierras fueron caracterizados por "la bondad, la mansedumbre, la hermosura, su simplicidad, humildad y buena naturaleza". Eran las víctimas propiciatorias, en un acontecimiento en el que el desenlace no podía ser de otra manera que no fuese su perdición total. De las decenas de naturales que en calidad de evidencia de su

\footnotetext{
6 Véase al respecto, Fray Bartolomé de las Casas. Historia de las Indias. Sociedad Dominicana de bib-
} liófilos. Santo Domingo. República Dominicana. Tomo I. Pág. 247. Año 1987. 
heroísmo lleva Colón a Castilla, mueren en el camino y en las mismas tierras Europeas la gran mayoría de ellos, y según los cronistas, solo 3 regresan con vida huyendo a la primera ocasión dos de ellos y permaneciendo el otro al servicio del español hasta su muerte.

El resultado del primer viaje de Colón al Nuevo Mundo no produjo de regreso a Castilla los tesoros y riquezas que todos esperaban. Permitió que el mundo científico despertara con un amplio territorio por descubrir, en el que encontrará espacio el conocimiento de la botánica, la Zoología, la medicina, la cartografía, la geografía, la Historia, la minería y muchos mas campos de desarrollo científico, como nunca antes se había `producido. Como si ello no fuese bastante, pocos años después las ansiadas riquezas lleguen a la España, que se convertía ya en potencia militar y económica mundial, con años de esplendor nunca antes visto y que una vez perdidos no se recobrarían jamás.

\section{Referencias bibliográficas}

- De las Casas Fray Bartolomé, Historia de las Indias. Sociedad Dominicana de bibliófilos. Año 1987.

- Martín. John, B. El destino dominicano. Santo Domingo. República Dominicana. 1975.

- Moya Pons. Frank, Manual de historia Americana. Barcelona, España. 6a . Edición. Año 1981.

- Washington Irvin, Vida y viajes de Cristóbal Colón. 1852. 